\title{
The Weft of Shanghai Fashion
}

Economic Networks in Shanghai's Modern Fashion Industry

\section{Carles Brasó-Broggi}

\section{OpenEdition}

\section{Journals}

\section{Electronic version}

URL: http://journals.openedition.org/chinaperspectives/6768

DOI: 10.4000/chinaperspectives.6768

ISSN: 1996-4617

\section{Publisher}

Centre d'étude français sur la Chine contemporaine

\section{Printed version}

Date of publication: 1 September 2015

Number of pages: 5-11

ISSN: 2070-3449

Electronic reference

Carles Brasó-Broggi, «The Weft of Shanghai Fashion », China Perspectives [Online], 2015/3 | 2015,

Online since 01 January 2017, connection on 28 October 2019. URL : http://journals.openedition.org/ chinaperspectives/6768; DOI : 10.4000/chinaperspectives.6768 


\title{
The Weft of Shanghai Fashion
}

\author{
Economic Networks in Shanghai's Modern Fashion Industry
}

\section{CARLES BRASÓ-BROGGI}

\begin{abstract}
Shanghai's modern fashion industry developed between the last decades of the nineteenth century and the 1930s and was an important step in China's industrialisation. The present article aims to define the relationship between production and consumption in Shanghai's modern fashion industry. One of the main characteristics of modern fashion is its ability to innovate by creating new and distinct trends while absorbing different influences. Shanghai modern fashion was an original mix of Chinese and foreign styles. The second determinant of this phenomenon is its capacity to be distinctive and reproducible at the same time. Shanghai's modern fashion therefore only emerged when the city was able to innovate and produce goods on a massive scale that were adapted to consumer tastes. To prove this relationship, the present article establishes concrete links between traders, industrialists, and retailers. The textile industry benefited from the outcome of a complex network that linked foreign trade, cotton mills, retail shops, and mass publicity. This paper analyses how this economic network was developed.
\end{abstract}

KEYWORDS: Shanghai modern fashion, textile industry, Chinese networks, garment industry, industrialisation of China.

\section{Introduction (1)}

W hat is modern fashion? It is believed that modern fashion appeared in the late eighteenth century, and what distinguishes it from past dress styles is the velocity by which modernity is able to transform and change. (2) The speed of the industrial spindle and the mechanical loom of the Industrial Revolution disrupted the production and price of garments in a way that had no parallel in history. The supply of textile products was radically altered by the factory system and further expanded through foreign trade. (3) Meanwhile, the patterns of consumption underwent a state of permanent transformation. ${ }^{(4)}$ This article aims to identify the networks that enabled the mass reproduction and consumption of clothes in China between the late nineteenth century and the Republican era. (5)

According to the classic German sociologist Georg Simmel, two seemingly contradictory concepts, imitation and delimitation, define modern fashion. ${ }^{(6)}$ On the one hand, fashion appears when an innovation distinguishes itself from any other past or present trend. The individual or social group that invents a new style is aiming to be distinctive and unique. On the other hand, a fashion is only successful when it is imitated by others and becomes increasingly popular, at which point it ceases to be distinctive and becomes massive. Modern methods of mass production, publicity, and shopping facilitate the progression from an original and isolated idea to the mass market. ${ }^{(7)}$ Thus, in modern fashion there is a balance between delimitation and imitation, exclusiveness and chain production, innovation and copying. While most of the academic literature on Chinese modern fashion has focused on its intangible assets, such as the question of representation and symbolism, this article examines the productive and commercial aspects of Shanghai's modern fashion. ${ }^{(8)}$

British, American, and European traders who arrived in China during the second half of the nineteenth century looked for an opportunity to sell mass-produced cotton goods from the factories of Lancashire and other in- dustrial centres. In 1890, cheap cotton textiles (yarn and cloth) from industrialised countries surpassed opium for the first time as the main imported products entering China. ${ }^{(9)}$ In a display of optimism, foreign merchants were convinced that the Chinese market would consume all the imported textiles, bringing huge profits and an everlasting source of wealth. But it turned to be a misperception - the so-called "myth of the China market" - as sales failed to reach the expected volumes. ${ }^{(10)}$ From the outset, Chinese mer-

1. The writing of this chapter was made possible through a post-doctoral grant from the Chiang Ching-kuo Foundation, European Program 2012-2014. I wish to express my greatest appreciation for the generosity of this organisation, without which this project would not have been possible. I would also like to thank Professor Gilles Guiheux for organising a workshop on the Chinese textile and garment industries in Shanghai and this special issue.

2. Fernand Braudel, Civilisation matérielle, économie et capitalisme (Civilisation and Capitalism), Paris, Armand Colin, 1979, pp. 233-250; Georg Simmel, Philosophie der Mode (The Philosophy of fashion), Berlin, Pan-Verlag, 1905 (Spanish version: Sobre la aventura. Ensayos de estética, Barcelona, Edicions 62, 2002, pp. 41-86). See also Kenneth Pomeranz, The Great Divergence. China, Europe and the Making of Modern World Economy, Princeton, Princeton University Press, 2000, pp. 152-153.

3. Robert C. Allen, The British Industrial Revolution in Global Perspective, Cambridge, Cambridge University Press, 2009, pp. 182-212.

4. On the revolution of consumption, see Jan de Vries, The Industrious Revolution. Consumer Behavior and the Household Economy, 1650 to the Present, Cambridge, Cambridge University Press, 2008, Pp. 4-7.

5. Antonia Finnane, Changing Clothes in China: Fashion, History, Nation, New York, Columbia University Press, 2008, p. 101.

6. Georg Simmel, Philosophie der Mode (Spanish edition), op. cit., pp. 49-55.

7. It was also called "pecuniary emulation" by Thorstein Veblen, The Theory of the Leisure Class, "Chapter 7: Dress as an Expression of the Pecuniary Culture," New York, Macmillan, 1899 (Spanish version: Teoría de la clase ociosa, Madrid, Alianza, 2004, pp. 177-196).

8. See for instance Antonia Finnane, Changing Clothes in China: Fashion, History, Nation, op. cit., and Sean Metzger, Chinese Looks: Fashion, Performance, Race, Bloomington, University of Indiana Press, 2014.

9. Albert Feuerwerker, The Chinese Economy, 1870-1949, Michigan, Ann Arbor Center for Chinese Studies, 1995, p. 61.

10. Yan Zhongping, Zhongguo mianfangzhi shigao (A Draft History of Cotton Spinning and Weaving in China), Beijing, Kexue chubanshe, 1963, pp. 59-67. See also Ralph M. Odell, Cotton Goods in China, Washington, Bureau of Foreign and Domestic Commerce, Special Agents Series No. 107, Government Printing Office, 1916; and finally James J. Lorence, Organized Business and the Myth of the China Market: The American Asiatic Association, 1898-1937, Philadelphia, Transactions of the American Philosophical Society, Vol. 71, No. 4, 1981. 
chants bought cotton yarn to weave domestically and grey and white foreign cloth to dye in urban workshops. ${ }^{(11)}$ Foreign cloth had to be adapted to Chinese tastes. Later, Chinese weavers and tailors used foreign intermediate products - mercerised yarns, iron gear looms, and chemical dyes - to create new clothes that mixed Chinese with Western and Japanese styles. But these innovations only became widespread in the 1920s, when Chinese industry was ready to recreate and reproduce these goods on a massive scale.

This article therefore defends the hypothesis that Shanghai's modern fashion emerged when modern industry was able to reproduce the innovations that adapted mass industrial products to the Chinese market. Only then did these innovations - which delimitated new urban and modern social classes in China - become truly popular. It also demonstrates that there was an intimate connection between the Chinese foreign cloth traders, the industrial entrepreneurs of the 1920s, and the tailors who invented the new styles of dress, a relationship that has not previously been observed, even though the circularity between production and consumption is fundamental to the fashion theory. ${ }^{(12)}$ This relationship was discovered by looking at the archives of the first foreign cloth association of Shanghai, the business documents of the first finishing textile industrial group, and several textile and fashion publications. (13) This article therefore looks at the different layers of the textile economy of Shanghai, considering the big mills, the small and medium workshops, and the retail shops, a relationship that has not attracted much academic interest. Cloth traders, cotton mill owners, retailers, tailors, and managers of department stores were in close contact, creating a complex network that determined the rise of Shanghai's modern fashion.

\section{The beginnings: Zhenhuatang and the foreign cloth traders}

In 1842, when Sir Henry Pottinger signed the Treaty of Nanking as envoy of Great Britain and put an end the First Opium War, Lancashire's cotton industries expected profits proportionate to the population of China. ${ }^{(14)}$ Even though commercial data soon demonstrated that this optimistic vision was exaggerated, trading companies kept considering China one of the world's most promising markets. Western firms that arrived in China tried to sell opium and textiles in the open ports, mainly in Shanghai. British cotton firms sold the stock to their own Chinese staff (compradors) or at auction near the harbours. ${ }^{(15)}$ Cotton goods were thus purchased by Chinese merchants, who would distribute and sell them to the final consumers. These merchants established the first wholesale and retail shops of "foreign cloth" (yangbu 洋布) in the centre of the International Concession, near the Bund, where stock was unloaded from ships. ${ }^{(16)}$

At the outset these stores sold all kinds of products and were run by Guangdong merchants who arrived with the British settlers, so they were called Cantonese shops (guanghuodian 广货店). Meanwhile, other shops started selling luxurious Chinese products from Beijing's imperial tradition, and they were called Beijing shops (jinghuodian 京货店). ${ }^{(17)}$ Soon, Ningbo merchants, a community that had always been active in the maritime trade, as well as local merchants from Shanghai and jiangsu, also joined the business, creating a mix of different origins and cultural influences that converged in Shanghai. ${ }^{(18)}$ The first stores specialising in foreign cloth appeared in the 1850s at the Eastern gate of the old city, where the cotton trade was traditionally undertaken, and in the newly built Nanjing Road. That was the centre of the foreign settlement, where Western exotic industrial products were first showcased beside traditional Chinese goods, which in fact looked exotic to Western settlers. It was in the intricate and cosmopolitan "chessboard alleys" (qipanjie 棋盘街) that separated the International Concession, the French Concession, and the Chinese territories that Shanghai's modern fashion emerged.

One of these stores was Dafeng 大丰, created in 1853 by Weng Nianfeng 翁年丰, a merchant from Ningbo. It started out as a wholesale shop specialised in British imported fabrics and was managed by a Huzhou merchant, Xu Chunrong 许春荣 (1839-1910). ${ }^{(19)}$ Xu had worked as a comprador for a foreign company that imported textile products from England (Reiss, Bradley \& Co.), and was also involved in the flourishing business of traditional local banking (qianzhuang 钱庄), which was controlled by Ningbo merchants. (20) In 1889 he joined a modern foreign bank, the German Deutsch-Asiatische Bank, but continued working with the foreign cloth trade through Dafeng. ${ }^{(21)}$ It was common for compradors to work and invest in different companies, Chinese and foreign-owned, and in different sectors such as textiles and banking. Under the management of Xu Chunrong, Dafeng was transformed into a big cloth distributor (zihao 字号) and one of the biggest sellers of foreign cloth in China, making a profit of up to 40,000 taels of silver a year. ${ }^{(22)}$ Xu Chunrong became a successful member of the emergent comprador class, the first to adopt a Western lifestyle in China, such as wearing Western suits. (23) In 1905, at age 66, Xu left Dafeng to work for Shao Qintao 邵琴涛, also a comprador and an early member of the Shanghai Chamber of Commerce. (24)

11. F. S.A. Bourne, Report of the Commission of the Blackburn Chamber of Commerce 1896-97, Blackburn, The North-East Lancashire Press Company, Bourne's Section, 1898, p. 288.

12. See Marco Pedroni, "Introduction," in Marco Pedroni, (ed.), From Production to Consumption: The Cultural History of Fashion, Oxford, Inter-disciplinary Press, p. XVI; see a discussion on the circulation between forces of production and fashion in Sean Metzger, Chinese Looks: Fashion, Performance, Race, op. cit., pp. 13-14.

13. Quoted archives are available at the Shanghai Municipal Archives (hereafter SMA), and are mainly related to the Zhenhuatang archives, from the Shanghaishi mianbu shangye tongye gonghui (Shanghai Cotton Cloth Trading Association) with the code S231, and the Dafeng company archives, from the Shanghai fangzhi xitong gechang quanzong huiji (Compiled Fonds of All the Enterprises of the Shanghai Textile System), with the code Q199-3.

14. British Parliamentary Papers, "Correspondence Relative to the Earl of Elgin's Special Missions to China and Japan, 1857-1859," London, Harrison and Sons, 1859, pp. 244-245.

15. Ralph M. Odell, Cotton Goods in China, op. cit., pp. 116-118; see also H. D. Fong (Fang Xiangting), Cotton Industry and Trade in China, Tianjin, Chihli Press, Inc., 1932, pp. 261-266; Shinza Sugiyama, "Textile Marketing in East Asia, 1860-1914," in S. D. Chapman (ed.), The Textile Industries, London, I. B. Tauris, 1997, p. 318; and finally Wang Chuifang, Yangshangshi Shanghai, 1843-1956 (The History of Foreign Merchants in Shanghai, 1843-1956), Shanghai, Shanghai shehui kexue chubanshe, 2007, pp. 28-47.

16. Shanghaishi mianbu shangye (The Business of Cotton Cloth in the City of Shanghai), Beijing, Zhonghua shuju, Zhongguo zibenzhuyi gongshangye shiliao congkan, 1979, pp. 8-14.

17. Ibid., pp. 6-8.

18. Regarding the role of Ningbo merchants in Shanghai, see Li Jian, Shanghai de Ningboren (The Ningboese of Shanghai), Shanghai, Shanghai renmin chubanshe, 2000.

19. See a short bio of Xu Chunrong in Shanghai dacidian (The Big Dictionary of Shanghai), Shanghai, Shanghai cishu chubanshe, Vol. 3, 2007, p. 1688.

20. Shanghai qianzhuang shiliao (Historical Materials of Shanghai's Traditional Banks), Shanghai, Shanghai renmin chubanshe, 1961, pp. 74-77.

21. Zhang Xiuli, "19 shiji Shanghai waishang qiyezhong de dongshi" (Board members in foreign companies in nineteenth century Shanghai), Shilin, No. 4, 2004, p. 7. See also Shanghai dacidian, op. cit., p. 1688.

22. Shanghaishi mianbu shangye, op. cit., p. 25 and p. 36

23. Ma Xueqiang and Zhang Xiuli, Churuyu zhongxi zhijian. Jindai Shanghai maiban shehui shenghuo, (Between East and West. The Life and Society of Shanghai Modern Compradors) Shanghai, Shanghai cishu chubanshe, 2009, pp. 278-289.

24. Shanghaishi mianbu shangye, op. cit., pp. 33-34. Regarding the development of the Shanghai Chamber of Commerce, see also Zhongping Chen, Modern China's Network Revolution: Chambers of Commerce and Sociopolitical Change in the Early Twentieth Century, Stanford, Stanford University Press, 2011. 
Between 1854 and 1855, new stores for foreign cloth were opened and spread to both sides of Suzhou Creek, as well as in the American Concession near what is now Sichuan Road. They sold all kinds of Western imported products, such as woollens, printed fabrics, shirts, handkerchiefs, umbrellas, neckties, and collars. ${ }^{(25)}$ The new shops - like Hengxing 恒兴, Zengtai 增泰, and Xietai 协泰 - had a similar structure to Dafeng: a predominance of Ningbo merchants and an average capital of less than 5,000 taels, built up by Chinese gentry, traditional bankers, and compradors. Meanwhile, in the old city, the traditional associations of Shanghai - the Traditional Cotton Cloth Association (tubu gongsuo 土布公所) and the Raw Cotton Association (mianhua gongsuo 棉花公所) - continued dealing with the domestic trade of raw cotton and traditionally-made fabrics, as usual. (26) These associations played a key role in the politics of the city, as they represented the public dimension of the professional and economic sectors. (27)

Foreign cloth sellers established a new association in order to represent their companies in Shanghai and to regulate the trade of foreign cloth sales under the name of the Zhenhuatang Foreign Cloth Association (Zhenhuatang yangbu gongsuo 振华堂洋布公所). (28) It was founded in 1858 by integrating a dozen foreign cloth shops and had a structure similar to the traditional associations that had been established in Shanghai since the Ming dynasty. All of them contained a temple, an office, a courtyard, and a set of rules written into a charter. Price negotiations, the establishment of fabric standards, fixed margins, and tax collection for the local government (as well as negotiations over the transit tax, or lijin) were among the most important functions of Zhenhuatang. ${ }^{(29)}$ It performed the function of a market regulator and had a quasi-democratic structure, with a board of voluntary directors elected from among its members. Zhenhuatang had a set of rules that clearly delimited the authority and powers assigned to the board, which governed for a period of two years. They also organised traditional rituals during festivals, as well as funerals and other services to the community. ${ }^{(30)}$

Xu Chunrong, who was a member of the board, managed a reform of the association in 1885, constructing a new building in the small alley of Nanjing Road. (31) Zhenhuatang was reformed again in 1912 to adapt to the new laws of the Republic of China, and a new school was added. Xu Chunrong was elected an honorary member of the board. In 1914, the Shanghai Municipal Council decided to enlarge the streets and buy properties in the centre of the city. The association benefited from the rising price of real estate in the heart of the International Concession by selling part of their property. With the earnings, the board member Li Baibao 李柏葆 managed to purchase a new property and build a new central office. ${ }^{(32)}$ The reassessment of the real estate in the centre of the International Concession of Shanghai and the rising price of foreign cloth during the First World War drove foreign cloth traders to become investors in the Shanghai's modern fashion industry in the years that followed.

Despite having inherited the tradition of the old merchant associations, Zhenhuatang was a modern institution that was intimately connected with the opening of Shanghai as a treaty port. According to the North China Herald, it was the most influential association, as far as foreign intercourse was concerned, with the bankers and the silk producer associations. ${ }^{(33)}$ Zhenhuatang participated in the semi-colonial and cosmopolitan life of the International Concession, such as the Silver Jubilee of 1893, organised by the Shanghai Municipal Council. (34) Shao Qintao, a member of Zhenhuatang, represented the interests of this association in the board of directors of the Shanghai Chamber of Commerce in one of the earliest meetings of this institution in 1905. ${ }^{(35)}$ From that year until the late 1920s, every annual session would have at least two members of Zhenhuatang in the Chamber. ${ }^{(36)}$ The trading network of Zhenhuatang extended far beyond Shanghai, even reaching the Japanese ports of Kobe and Yokohama, where foreign cloths merchants from Ningbo were established and textiles were re-exported from Shanghai. ${ }^{(37)}$ In short, Zhenhuatang was an early product of the cosmopolitan city of Shanghai that absorbed multiple cultural elements, even though its structure resembled a traditional Chinese guild.

In 1918, a stone pillar was erected in memory of the association, explaining how it was founded in the British Concession and how it was reformed. (38) It was one of the first civil associations of Chinese origin that appeared in the British Concession of Shanghai. (39) Zhenhuatang survived without change until the generalisation of the boycotts against foreign products and the establishment of the Nanjing government. The association had strong ties with foreign companies and the trade blockades affected the foreign clothing business. ${ }^{(40)}$ In order to avoid the boycotts and take part in the official registers of national associations under the new laws of the Nanjing government, the director Yu Baosan 余葆三 suggested changing the name of the company to "Zhenhuatang Cotton Cloth Association" and registering it with the Shanghai Cotton Cloth Trading Association (Shanghaishi mianbu tongye

25. Li Jian, Shanghai de Ningboren, op. cit., p. 120.

26. Xu Xinwu, Jiangnan de tubushi (The History of the Domestic Cloth of Jiangnan), Shanghai, Shanghai shehui chubanshe, 1992, p. 252. See also Linda Cooke Johnson, Shanghai: From Market Town to Treaty Port, 1074-1858, "Chapter 2: Cotton:The Development of Shanghai County," Stanford, Stanford University Press, 1995, pp. 43-59; and Lu Hanchao, "Arrested Development: Cotton and Cotton Markets in Shanghai, 1350-1843," Modern China, Vol. 18, No. 4, 1992, p. 491.

27. Xiaoqun $\mathrm{Xu}$, Chinese Professionals and the Republican State: The Rise of Professional Associations in Shanghai, 1912-1937, Cambridge, Cambridge University Press, 2000, pp. 12-13.

28. Zhenhuatang archives, "Shanghaishi mianbu shangye tongye gonghui, xiujian zhenhuatang yangbu gongsuo bing chuang shiwusuoji beituoben" (Commemorative stone about the construction of Zhenhuatang Foreign Cloth Association), 1918, SMA, S231-1-2, p. 1.

29. Zhenhuatang archives, "Zhenhuatang yangbu gongsuo guize" (Rules of Zhenhuatang Foreign Cloth Association), SMA, Q116-1-21-4, pp. 4-5; see also Shanghaishi mianbu shangye, op. cit., p. 11; and Ralph M. Odell, Cotton Goods in China, op. cit., pp. 119-120.

30. Ibid., p. 3

31. Zhenhuatang archives, "Shanghaishi mianbu shangye," op. cit., SMA, S231-1-2, p. 1.

32. Ibid., p. 1

33. See North China Herald, "The native guilds of Shanghai," 24 November 1893, p. 823.

34. See Bryna Goodman, "Improvisations on a Semicolonial Theme, or, How to Read a Celebration of Transnational Urban Community," The Journal of Asian Studies, Vol. 59, No. 4, 2000, pp. 900-904.

35. See the member list of the board of the Shanghai Chamber of Commerce in Shanghai zongshanghui lishi tulu (Catalogue of the History of the Shanghai Chamber of Commerce), Shanghai, Shanghai guji chubanshe, 2011, p. 24; For more detailed minutes, see Shanghai zongshanghui zuzhi shiliao huibian, (Compilation of Historical Materials of the Shanghai Chamber of Commerce) Shanghai, Shanghai guji chubanshe, Vol. 1, 2004, p. 16.

36. Shanghai zongshanghui zuzhi shiliao huibian, op. cit.

37. Kazuko Furuta "Kobe Seen as a Part of the Shanghai Trading Network: the Role of Chinese Merchants in the Re-Export of Cotton Manufactures to Japan," in Kaoru Sugihara (ed.), Japan, China, and the Growth of the Asian International Economy, 1850-1949, Oxford, Oxford University Press, 2005, pp. 39-40.

38. Zhenhuatang archives, "Shanghaishi mianbu shangye," op. cit., SMA, S231-1-2, p. 1.

39. Li Xia, "1918 nian Shanghaishi mianbushangye tongye yijian zhenhuatang yangbu gongsuo bingchuang shiwusuo ji beita" (A monument about the reorganisation of the central office of Zhenhuatang Foreign Cloth Association, of the Shanghai Cotton Cloth Association in 1918), available at www.archives.sh.cn/dajc/201212/t20121205_37436.html (accessed on 10 May 2015), website of the Shanghai Municipal Archives, 2012.

40. Zhenhuatang archives, "Shanghaishi mianbu shangye tongye gonghui, zhenhuatang yangbu gongsuo dongshihui he zenhuatang mianbu gongsuo zhixing weiyuanhui yiji zaici shiqi neige cihui huiyuan dahui deng huiyi jilu" (Minutes of Zhenhuatang and its conversion to Zhenhuatang Cotton Cloth Association), 1927-1929, SMA 231-1-27, pp. 31-33. 
gonghui 上海市棉布同业公会), which encompassed all kind of cotton cloth shops. ${ }^{(41)}$

At that time, the market had already changed from the domination of foreign goods to the boom of fashion products made in Shanghai. According to a survey in 1934, there were a total of 573 cotton cloth shops in Shanghai that sold all kinds of products, traditional, modern, foreign (mainly made in the U.S., Britain, and Japan), and Chinese. ${ }^{(42)}$ Half of them were individually-owned companies and the other half were partnerships, mainly among family members, with an average of four people employed (only one company of this kind was registered with shares). Among these shops, 296 (50\%) sold in retail and 237 (40\%) were wholesalers, while the rest combined both types of business. Most were based in the International Concessions. Foreign cloth traders were among the first Chinese merchants to participate actively in the commercial and civilian life of modern Shanghai, playing a key role in the establishment of the Shanghai Chamber of Commerce. According to American textile expert Ralph M. Odell, who visited Shanghai at the beginning of the twentieth century, "The organization among the cotton goods dealers in China is one of the strongest in the world." (43)

\section{The rise of the modern fashion industry in Shanghai}

At the outset, the members of Zhenhuatang sold bulk fabrics in bales of folded pieces without adding value to them. The evolution of these merchants from trading to manufacturing took decades, as they had to gain the know-how of modern manufacturing. In 1912, the Chinese textile industry was still very underdeveloped. The cotton sector had not reached 1 million spindles, while British India reached 2.3 million and Japan 6.1. (44) Throughout China there were only 32 cotton spinning mills, 24 Chineseowned and 8 foreign-owned, mainly in Shanghai. In weaving figures were even weaker; China had only 5,000 industrial looms for cotton weaving (not counting workshops), which was totally insufficient. ${ }^{(45)}$ The 70 silk filatures in Guangdong and the Yangzi Delta produced silk yarn mainly for export. ${ }^{(46)}$ At the time, the industries of wool, linen, dyeing, shoes, underwear, shirts, leather, and artificial fibres were non-existent except for some workshops. The majority of the population of China produced their clothes domestically following traditional practices. ${ }^{(47)}$

First some technology had to be imported: industrial spindles, automatic looms, sewing machines (the famous Singer, which entered China in the 1860s), chemical dyes, needles, dyeing machinery, etc. (48) In the beginning, white foreign cloth was dyed in traditional workshops with chemical dyes. But in the 1890s, Ningbo merchants who had been active in the port of Yokohama imported the first wooden and iron Japanese looms that would be used in small workshops to manufacture wider cloth with imported highcount yarns. ${ }^{(49)}$ The import of textile technology gained momentum just after the First World War, allowing the take-off of the Shanghai's modern fashion industry. ${ }^{(50)}$

Meanwhile, small and medium weaving workshops flourished, profiting from the expansion of the electrical grid and other facilities in Shanghai. The Japanese wooden and iron gear looms were useful for weaving a wider cloth that could be patterned using dyed or mercerised yarns. In 1912, dozens of workshops that experimented with these new technologies produced new kinds of fabrics that were called "improved cloth" (gailiang tubu 改良土布), such as the "Ningbo fabric" (yongbu 角布), referring to the region of origin of the owners of these workshops. ${ }^{(51)}$ These garments were a mixture of Chinese, Japanese, American, and European styles and used intermediate products (high-count yarns, machinery, etc.) from various countries as well. Because the most fashionable products were made of high-count yarns that had to be imported from abroad, the weaver still had to wait around six months to receive orders. ${ }^{(52)}$

Even though big cotton and silk mills that used Chinese cotton and silk have received most of the academic attention, by the mid-1930s, workshops with fewer than 30 workers still represented around $60 \%$ of the industries of Shanghai. ${ }^{(53)}$ China's workshops played a prominent role in the development of a textile industry that reached the capacity to produce all kinds of products. Big mills mainly produced coarse yarn, while very few of them had weaving and dyeing departments. In fact, some of the first integrated mills that appeared in the 1920s and 1930s begun as workshops. And because these workshops began working with imported high-count yarns and cloths, traders and industrialists forged an intimate collaboration. One of these workshops was Dafeng 达丰, not to be confused with the foreign cloth firm in Nanjing Road that had the same Romanisation but not the same Chinese characters (大丰). The similarity of names may not be a coincidence, as the new industrial workshops copied the names of the trading pioneers that had been lucky enough to sell the foreign products they now wanted to copy. A good range of names referred to the first foreign cloth firms, such as Dafengheng 大丰恒, Renfeng 仁丰, Meifeng 美丰, etc. Dafeng was founded by the Ningbo merchant Wang Qiyu 王启宇 (18831965), whose partners included four members of Zhenhuatang:Yu Baosan, Li Baibao, Zhou Xingbo 周幸伯, and the traditional banker, also from Ningbo, Xu Chengxun 徐承勋. ${ }^{(54)}$ The members of Zhenhuatang and the traditional bankers raised capital to transform the workshop into a big integrated industrial group.

Dafeng appeared in 1912 in the International Concession as a workshop with fewer than 30 workers. The workshop dyed and mercerised imported

41. Ibid., pp. 90-92; See also Zhenhuatang archives, "Shanghaishi mianbu shangye tongye gonghui, zhenhuatang mianbu gongsuo ji Shanghai mianbuye tongye gonghui huiyuan dahui he zhijian changwei huiyi jilu" (Proceedings of the meetings of the committee and general assembly of the joint Zhenhuatang Cotton Cloth Association and the Shanghai Cotton Cloth Trading Association), 1930-1933, SMA, S231-1-28, pp. 36-37. About the new laws of the Nanjing government for professional associations, see Xiaoqun $\mathrm{Xu}$, Chinese Professionals and the Republican State: The Rise of Professional Associations in Shanghai, 1912-1937, op. cit., pp. 94-103.

42. Mianbuye (The Business of Cotton Cloth), Shanghai, Shanghaishi shanghui shangwu kebian, 1934, p. 23.

43. Ralph M. Odell, Cotton Goods in China, op. cit., p. 119

44. Freda Utley, Lancashire in the Far East, London, George Allen \& Unwin, 1931, p. 23

45. Yan Zhongping, Zhongguo mianfangzhi shigao, op. cit., pp. 177-188.

46. On the silk industry, see Robert Y. Eng, "Chinese Entrepreneurs, the Government, and the Foreign Sector: The Canton and Shanghai Silk-reeling Enterprises," Modern Asian Studies, Vol. 18, No. 3, 1984, pp. 353-370, in particular p. 356.

47. Xu Xinwu and Byung-kun Min, "The Struggle of the Handicraft Cotton Industry Against Machine Textiles in China," Modern China, Vol. 14, No. 1, 1988, pp. 31-49.

48. Antonia Finnane, Changing Clothes in China: Fashion, History, Nation, op. cit., pp. 116-119.

49. Xu Xinwu, Jiangnan tubushi, op. cit., pp. 407-409.

50. H. D. Fong, Cotton Industry and Trade in China, op. cit., pp. 83-85.

51. Xu Xinwu, Jiangnan tubushi, op. cit., p. 435. See also Huang Hanmin and Xu Xinwu, Shanghai jindai gongyehua (The Modern Industrialisation of Shanghai), Shanghai, Shanghai shehui kexue chubanshe, p. 110.

52. Dafeng Archives, "Dafeng ranzhi gufen youxian gongsi, gudong dingqi, linshi huiyi jilu" (Shareholder meeting minutes, regular and temporary sessions), 1921-1937, SMA, Q199-3-8, p. 2.

53. D. K. Lieu (Liu Dajun), The Growth and Industrialization of Shanghai, Shanghai, China Institute of Economic and Statistical Research, 1936, p. 97.

54. Dafeng Archives, "Dafeng ranzhi gufen youxian gongsi, dongshihui jilu" (Minutes of the Board of Directors of Dafeng Weaving and Dyeing Company), 1921-1927, SMA, Q199-3-7, June 1921, p. 1. The same names appear in the "minutes of Zhenhuatang", op. cit., SMA, S231-1-27, p. 90. 
high-count yarns with two dyeing vats imported from Japan. ${ }^{(55)}$ They experimented with mercerisation (siguang 丝光), a process that brings brightness into the cotton yarn and makes it look similar to silk. This product was sold in Shanghai to tailors and other weaving workshops (especially stocking workshops). (56) Short afterwards, Dafeng also started to dye fabrics, and in 1916 it became the first company in China to use chemical dyes to produce khaki cloth, a technique that became famous in the renovation of men's attire under the influence of Western and Japanese military uniforms. ${ }^{(57)}$

With the First World War, textile imports ground to a standstill, causing a sharp increase in the price of textile goods and bringing high profits to Chinese workshops and traders that kept or could produce a provision of high-count yarn and cloth. The drop in imports combined with high demand also created strong incentives for industrial investment. Under these circumstances, some members of the Zhenhuatang network decided to invest in an industrial undertaking. The business was expanded by building a new spinning mill, the Zhentai Spinning Mill (Zhentai fangzhi chang 振泰 纺织厂), and a new weaving and dyeing mill beside the spinning factory, Dafeng Weaving and Dyeing Mill (Dafeng ranzhichang 达丰染织厂). The two mills, placed one beside the other, were inaugurated together in November 1922. ${ }^{(58)}$

The first meetings of the shareholders of Dafeng took place at the headquarters of Zhenhuatang, in the old chessboard alleys near Nanjing Road. (59) The relationship between Dafeng, Zhentai, and Zhenhuatang was therefore very intimate. The much older Zhenhuatang association gave Dafeng a kind of institutional protection during its first years. Yu Baosan was the first director of the board of Dafeng and its largest investor. Meanwhile, Li Baibao became the director of the board of Zhentai, while also being in charge of Zhenhuatang. ${ }^{(60)}$ Both Li Baibao and Yu Baosan assumed executive positions in Zhenhuatang as well as in Dafeng and Zhentai during the 1920s.

In 1927, Dafeng was one of the first companies to use a modern printing machine imported from Great Britain. ${ }^{(61)}$ At the time, they were at the forefront of the technological process and had a massive production. Dyed and printed fabrics in silk and cotton, as well as mercerised yarns, became fashionable with the rise of the qipao 旗袍, a type of dress that emerged around 1926. ${ }^{(62)}$ Although the best qipaos were made of silk, cheaper versions in cotton and cotton-silk blends were produced for mass consumers. American publicist Carl Crow, with long experience in Shanghai, provided one of the best descriptions of the fashion for qipaos. He wrote that Shanghai tailors used to buy calicos (printed cotton cloth) from Manchester to manufacture this new kind of dress, as well as Japanese sateens as a substitute for silk. ${ }^{(63)}$ However, because both British and Japanese products were affected by the nationalist boycotts, Chinese producers ultimately gained the advantage in the business.

In 1929, Gu Zipan 顾子槃 joined Dafeng and was elected supervisor in the Dafeng shareholder meeting. ${ }^{64)} \mathrm{Gu}$ Zipan had worked at the older Dafeng, the foreign cloth shop run by Xu Chunrong that was behind the founding of Zhenhuatang. ${ }^{(65)}$ In 1929, Gu Zipan also became the president of Zhenhuatang's board of directors, just as Xu Chunrong had done 50 years earlier with the association and the trade firm. ${ }^{(66)} \mathrm{Gu}$ Zipan had worked as a comprador for the British firm Reiss, Bradley \& Co., the same company that had given Xu Chunrong his start, and he was the younger brother of Shao Qintao's wife, the successor of Xu Chunrong at the Dafeng foreign cloth shop. ${ }^{(67)}$ This relationship demonstrates the intimate connection between traders and industrialists.

In 1934, there were more than 1,000 textile mills and workshops in Shanghai, with 250 big cotton and silk spinning mills (the ones that have attracted the attention of scholars), while the rest were smaller factories and workshops focusing on finishing processes such as weaving (without spinning), dyeing, printing, and knitting. Small industries and workshops were even more dominant in the clothing industry, especially in hosiery, hats, umbrellas, underwear, handkerchiefs, towels, and all kind of modern garments and accessories. ${ }^{(68)}$ This mixture of various production sizes allowed the market to constantly innovate and adapt to consumer tastes, not only because production and consumption were in close contact, but also because a complex network linked small workshops with the big mills.

\section{From mass production to mass retail}

During the 1920s, even the vertically integrated factories did not sell directly to the final consumers but rather to other distributors, retailers, and tailors. The first tailors who could make foreign-style clothes in Shanghai appeared just beside the Zhenhuatang headquarters. In fact, some of these tailor shops were originally cloth shops that had learnt the art of cutting and sewing. At the end of the nineteenth century, a group of tailors from Fenghua 奉化 - a county in Ningbo - established new stores in Nanjing Road. ${ }^{(69)}$ They cut and sewed modern Western garments by using imported cloth delivered by the importers of Zhenhuatang. Most of them opened during the first decade of the twentieth century, including Wangxingchang

55. Dafeng Archives, "Dafeng ranzhi gufen youxian gongsi, gudong dingqi, linshi huiyi jilu" (Shareholder meeting minutes of Dafeng Weaving and Dyeing Company, regular and temporary sessions), June 1921, SMA Q199-3-8, pp. 1-7.

56. Ibid., pp. 1-2

57. According to Wang Fuyuan, the fifth son of Wang Qiyu, see Wang Fuyuan, "Zhongguo jiqi yinran zhi shouchuangzhe, gushiyejia Wang Qiyu chuanlüe" (A brief biography of Wang Qiyu, pioneer of the industrial dyeing in China), in Zhoushan wenshiliao (Historical Materials of Zhoushan), Hangzhou, Zhejiang renmin chubanshe, 1981, p. 116.

58. North China Herald, 11 November 1922, p. 376; see also Shenbao, 4 November 1922, in Sun Jiagen, Shenbao Ningbobang qiye shiliao (Historical Materials of the Ningbo Merchant Group in Shenbao), Ningbo, Ningbo chubanshe, 2012, p. 137

59. Dafeng Archives, "Dafeng ranzhi gufen youxian gongsi, gudong dingqi, linshi huiyi jilu," op. cit., March 1923, SMA Q199-3-8, pp. 10-13. The company continued to hold its shareholders meetings at Zhenhuatang until 1933.

60. Yan Zhongping, Zhongguo mianfangzhi shigao, op. cit., p. 357.

61. Dafeng Archives, "Dafeng ranzhi gufen youxian gongsi, dongshihui jilu," op. cit., April 1926, SMA Q199-3-7, p. 138

62. There has been a wealth of research on the qipao. See Antonia Finnane, "What Should a Chinese Woman Dress?," Modern China, Vol. 22, No. 2, 1996, pp. 99-131; and Antonia Finnane, Changing Clothes in China: Fashion, History, Nation, op. cit., "Chapter 6: Qipao China"; See also Hazel Clark, "The Cheung Sam: Issues of Fashion and Cultural Identity," in Valerie Steel and John S. Major (eds), China Chic: East Meets West, New Haven, Yale University Press, 1999, pp. 154-165. For recent studies in Chinese, see Yuan Ze and Hu Yue, Bainian yishang: 20 shiji Zhongguo fuzhuang liubian (A Hundred Years of Costumes:The Transformation of Twentieth Century Chinese Clothes), Beijing, Sanlian shudian, 2010, pp. 154-168; Xu Hualong, Shanghai fuzhuang wenhuashi (The History of Shanghai's Garment Culture), Shanghai, Donghua chubanshe zhongxin, 2010, pp. 168-176. On the reception of the qipao in the United States, see Sean Metzger, Chinese Looks: Fashion, Performance, Race, op. cit., "Part Two: the Qipao."

63. Carl Crow, 400 Million Customers. The Experiences, Some Happy, Some Sad, of an American in China and What They Taught Him, Norwalk, East Bridge, 1937 (re-ed. 2003), p. 22; On the Japanese cotton sateens, see Takeshi Abe, "The Chinese Market for Japanese Cotton Textile Goods, 19141930," in Kaoru Sugihara (ed.), Japan, China, and the Growth of the Asian International Economy, 1850-1949, op. cit., pp. 88-89.

64. Dafeng Archives, "Dafeng ranzhi gufen youxian gongsi, gudong dingqi, linshi huiyi jilu," op. cit., March 1929, SMA Q199-3-8, p. 66.

65. Gu Zipan worked for the original Dafeng cloth distributor in 1916, according to Shanghai zongshanghui zuzhi shiliao huibian, op. cit., p. 169.

66. Zhenhuatang archives, "Shanghaishi mianbu shangye tongye gonghui, xiujian zhenhuatang yangbu gongsuo bing chuang shiwusuoji beituoben," op. cit., SMA, S231-1-2, p. 1.

67. Shanghaishi mianbu shangye, op. cit., p. 34.

68. D. K. Lieu, The growth and industrialization of Shanghai, op. cit., pp. 189-199.

69. Antonia Finnane, Changing Clothes in China: Fashion, History, Nation, op. cit., pp. 111-120. 
王兴昌 and Yuchangxiang 裕昌祥. (70) Following their Zhenhuatang predecessors, the majority of tailors came from Ningbo Province, and even from the same town, and some even shared the same surname. In 1910, Wang Caiyun 王才运 (1879-1931), a former student in Japan, opened a store in Shanghai's Nanjing Road called Rongchangxiang 荣昌祥. ${ }^{(71)}$ It sold all kind of Western men's clothes and accessories to final consumers. As with the foreign cloth sellers, the tailors of foreign clothes also created their own professional associations. ${ }^{(72)}$

Sun Yat-sen's Republican Revolution radically changed the speed of fashion, accelerating the mixtures of styles between East and West (the socalled zhongxi hebi 中西合璧). And just as the Chinese referred to Westerners as "red haired people," tailors who made Western clothes in Shanghai were called "red gang tailors" (hongbang caifeng 红帮裁缝). ${ }^{(73)}$ In fact, among the theories of the origins of Sun Yat-sen's famous jacket, one traces its origins to Rongchangxiang. Apparently, in 1916 Sun asked Wang Caiyun to create a jacket that was a mixture of suit and British uniform. The revolutionary leader already knew the reputation of Ningbo tailors after meeting them in Yokohama, where he travelled around 1905. Sun Yat-sen's suit was made by Wang Caiyun, and it was inspired by European uniforms that had previously been copied by Japanese tailors, although the traditional Chinese round collar made it original and Chinese as well. (74) Innovations such as the qipao and the Sun Yat-sen jacket came from this particular mixture of influences and adaptations to Chinese tastes.

After Sun Yat-sen's Revolution, professional tailors were in high demand. According to the Shanghai Municipal Council, in 1921, the price of uniforms rose $20 \%$ due to the increasing demand for tailors all over the city. ${ }^{(75)}$ The Shanghai Municipal Council had problems securing tailors to produce official uniforms, as the tailors tended to establish their own businesses and leave. ${ }^{(76)}$ Tailors and retail shops typically attached the character $j i$ 记 to the name of the owner and were small establishments. ${ }^{(77)}$ In 1933, there were approximately 2,000 tailor shops in Shanghai and about 40,000 professional tailors registered in the professional associations. ${ }^{(78)}$

The relationship between small tailoring and retail companies and the big weaving and dyeing mills was also close and shaped by the same networks. The investors in the Dafeng Weaving and Dyeing Mill, Yu Baosan and Li Baibao, also owned textile firms that sold cotton cloth and yarns under the names Chenxingji 陈星记 and Libaiji 李柏记. (79) Compared to the big distributors, which were called hao 号, these companies were mainly small and family-owned. During the 1920s and 1930s, fabric shops and tailor shops developed a close relationship with industrial producers because consumers wanted goods made in China. Especially in the case of dyeing and finishing mills, the relationship between small shops and industries became strong. In the Dafeng shareholder list of 1928, besides the members of Zhenhuatang, 160 small retailers (with the character ji on their name) owned 4,758 shares of the industrial company (out of a total of 10,000), almost half of the social capital. ${ }^{(80)}$

Tailors and retailers informed the producers of new trends in the consumer markets. In Dafeng's annual shareholder meeting in 1929 at the Zhenhuatang headquarters, awareness of the latest trends was evident: they noticed the success of the qipao and the popularity of Indanthrene dyes (yindan shilin 阴丹士林) in women's clothing. ${ }^{(81)}$ It was said of these chemical dye formulas of the aniline type that "rain or shine, the colour never fades" (rishai yulin yongbu tuishai 日晒雨淋永不退色), but this sentence was patented by the powerful chemical German importer I. G. Farben, who held the patents for these dyes and didn't allow other brands to use the slogan. ${ }^{(82)}$
A conflict emerged, and ultimately I.G. Farben was granted exclusive rights to the so-called "Indanthrene trade-marks" (or I. G.), which included the blue dye that imitated indigo, one of the most popular. Its products were advertised with a simple drawing of sun and rain (one of the most recognisable trademarks in China at that time). ${ }^{(83)}$ No matter which dyeing company finished the cloth, the product was to be labelled as I. G. Farben's Indanthrene cloth, and the textile company could not design, print, advertise or use the Indanthrene name for any other product. (84) Some dyeing companies, such as Dafeng, bought dyes from other European companies and made their own brands (such as the famous Peacock [kongque] 孔雀 brand of Dafeng), and advertisements referred to Dafeng as the original and unique Chinese pioneering brand. ${ }^{(85)}$ In 1937, research carried out by the registrar's office of the Nanjing government compiled 6,487 industrial trademarks in China. One third of them $(2,173)$ came from the textile and garment industries, which gives an idea of the importance of this sector in the Chinese economy. ${ }^{(86)}$ These brands were advertised in newspapers as well as in publications for textile experts, tailors, and textile students.

70. Chen Wanfeng, Zhongguo hongbang caifeng fazhanshi (The History and Development of the Chinese Red Tailors), Shanghaijuan, Shanghai, Huadong daxue chubanshe, 2007, pp. 42-44. See a list of tailors and other materials at Ningbo's Textile Museum.

71. Wang Jiazhen, "Shanghai xifuye bizu Wang Caiyun" (The pioneer of Western dress, Wang Caiyun), in Lu Pingyi (ed.), Chuangye Shanghaitan: Ningboren zai Shanghai (Building Shanghai Tan: The Ningboese in Shanghai), Shanghai, Shanghai kexue jishu wenxian chubanshe, 2003, pp. 208-216.

72. These associations were the Sanruitang gongsuo (Sanruitang Association), the Shanghaishi shizhuang shangye tongye gonghui (the Association of the Fashion Trade of Shanghai) and the Shanghaishi chengyi shangye tongye gonghui (the Association of Shanghai Cloth Shops); see Chen Wanfeng, Zhongguo hongbang caifeng fazhanshi (The History and Development of the Chinese Red Tailors), op. cit., pp. 79-82, pp. 224-229.

73. See Chen Wanfeng, ibid.

74. Antonia Finnane, Changing Clothes in China: Fashion, History, Nation, op. cit., p. 182; See also Wang Jiazhen, "Shanghai xifuye bizu Wang Caiyun" (The pioneer of Western dress, Wang Caiyun), op. cit., p. 211.

75. "Shanghai gonggong zujie gongbuju zongbanchu guanyu wanguo shangtuan zhifu caifeng de feiyong, 1921-30" (Shanghai Municipal Council, regarding the cost of tailors), SMA, U1-3-1159.

76. "Shanghai gonggong zujie gongbuju zongbanchu guanyu hanbili gongxue he nüxiao caifeng shi, 1922-26" (Shanghai Municipal Council, about the tailors of several girl schools of the city), 1921, SMA, U1-3-2184

77. Mianbuye, op. cit., pp. 40-86; See also Antonia Finnane, "Tailors in 1950s Beijing: Private Enterprise, Career Trajectories, and Historical Turning Points in the Early PRC," Frontiers of History in China, Vol. 6, No. 1, 2011, p. 131

78. Quoted in Chen Wanfeng, Zhongguo hongbang caifeng fazhanshi (The History and Development of the Chinese Red Tailors), op. cit., p. 8.

79. Shanghai zongshanghui zuzhi shiliao huibian, op. cit., p. 118 and p. 357.

80. Dafeng archives, "Shanghai dafeng ranzhi gufen youxian gongsi zhangcheng, gudong mingce, qingce biaoshi ji shenqing zhuce zhizhao de baogao, 1920-1928" (Compendium of register and permissions materials of Dafeng Weaving and Dyeing Company), SMA Q199-20-89, pp. 14-56.

81. Dafeng Archives, "Dafeng ranzhi gufen youxian gongsi, gudong dingqi, linshi huiyi jilu," op. cit., March 1929, SMA Q199-3-8, pp. 63-64.

82. Gongshang banyuekan (Industry and commerce bi-weekly), Vol. 1, No. 12, 1929, pp. 47-51.

83. Wang Fuyuan, "Zhongguo jiqi yinran zhi shouchuangzhe, gu shiyejia Wang Qiyu chuanlüe" (A brief biography of Wang Qiyu, pioneer of the industrial dyeing in China), op. cit., p. 116.

84. See Zhang Zhenhou, "Ranliao hangyehua dangnian" (The days when the dyestuff business was transformed), Shanghai, Shanghai wenshi ziliao cungao, Vol. 7, 1965 (re-ed. 2001), pp. 70-81.

85. See the report of the Shanghai Chamber of Commerce in Gongshang Shiliao (Historical Materials on Industry and Trade), Shanghai, Shanghai Zongshanghui bian, 1935, p. 191; See also Ranzhifang Zhoukan, Vol. 3, No. 1, 1937, p. 1853. See also a recent explanation on the dispute between Dafeng and I. G. Farben by the granddaughter of Wang Qiyu, Eleanor Wong, "A History of the Wong Family Textile Business," Hong Kong, Harmony Day Services, Ltd. (private book), 2014, available at the HK Industrial History Website http://industrialhistoryhk.org (accessed on 19 June 2015). I would like to thank Hugh Farmer and Carey Vail for their kindness in sending me this manuscript. For a recent study of the advertisements of Dafeng, see Zuo Xuchu, Bainian Shanghai minzu gongye pinpai (A Century of Shanghai's National Industrial Brands), Shanghai, Shanghai wenhua chubanshe, 2012, pp. 42-45.

86. Ibid. 
Finally, the communication between production and consumption culminated in the establishment of department stores by the textile firms that jammed Nanjing Road. ${ }^{(87)}$ These big retailers appeared right next to the "red tailors" of Nanjing Road, and allowed Shanghai fashion to become even more mass-oriented. The whole street was totally transformed with neon lights and entertainment venues such as the Wing On Department Store (Yong'an 永安), founded in 1918 by the Guo brothers from Guangdong Province. ${ }^{(88)}$ The company had textile mills and a tailoring department in its department stores. However, this company did not initially have a finishing department and was a customer of Dafeng Weaving and Dyeing Mill. In 1927, more than 10,000 pieces of cloth were dyed, bleached, and patterned in Dafeng for the Wing On department stores. ${ }^{\left({ }^{89}\right)}$ Finishing companies such as Dafeng also produced goods for other firms for a fee or commission. In 1928, the price for this service could range from 1 tael for bleaching 40 yards of shirting to 2.1 taels for dyeing 40 yards of shirting in Indanthrene blue. ${ }^{\left({ }^{90}\right)}$ However, in the next decade Wing On developed its own dyeing department and even published its own fashion journal, the popular Wing On Monthly (Yong'an yuekan 永安月刊). (91) Wing On was therefore the first business to integrate the entire modern fashion business.

\section{Conclusion}

This article aims to shed new light on the relationship between production and consumption in the study of Shanghai's modern fashion. The most visible aspect of Shanghai's modern fashion - the dazzling clothes that cinema stars wore during social events and in jazz ball rooms - is one of the most popular images of the city. Shanghai became the "Paris of the Orient," and the momentum of fashion, modernity, and transgression was revealed in the national and international press, cinema, music, and a rich literature. Today, the visitor can still find the modernist architecture that testifies to this amazing period. However, the rise of Shanghai's modern fashion industry was determined by a complex economic network of businesses and entrepreneurs that have remained relatively unknown.

From the mid-nineteenth century, the foreign cloth traders of Shanghai introduced new and distinctive styles of clothing by mixing different traditions and by experimenting with modern methods of production, while keeping alive traditional forms of organisation such as small and medium workshops and regional associations. These traders turned to industrial entrepreneurship during the First World War and built integrated textile factories that could produce new goods on a massive scale. It was a cosmopolitan network, but also a local one, where the community of Ningbo merchants played a dominant role. The present article identifies and explains how trade networks participated in the industrial and consumption booms that took place in Shanghai and the Yangzi Delta during the 1920s and 1930s. The strong ties that existed between producers, traders, and retailers allowed the city of Shanghai to constantly innovate and adapt new technologies to local consumer tastes.

These interactions between the supply side, the retail world, and the consumer markets also reflect Shanghai's late industrialisation and its problems, such as long gaps between the importation of foreign products and the consolidation of a domestic mass production system. It was only after 1920 that a complex network of traders, producers, and retailers developed integrated companies that could adapt their production capacity to the new urban consumption demands. These delays may be attributed to difficulties of technology transfer, especially in the last stages of the production process (dyeing and printing), which developed later than spinning and weaving.

\section{ICarles Brasó-Broggi is an associate lecturer at Universitat Oberta} de Catalunya (UOC), Spain.

Avinguda Tibidabo, No. 45-49, Barcelona 08035, Spain

(cbraso@uoc.edu).
87. Wellington K. K. Chan, "Selling Goods and Promoting a New Commercial Culture: the Four Premier Department Stores on Nanjing Road, 1917-1937," in Sherman Cochran (ed.), Inventing Nanjing Road. Commercial Culture in Shanghai, 1900-1945, Ithaca, Cornell East Asia Series, 1999, pp. 1960.

88. Wellington K. K. Chan, "Selling Goods and Promoting a New Commercial Culture:The Four Premier Department Stores on Nanjing Road, 1917-1937," art. cit., pp. 19-36; see also Antonia Finnane, Changing Clothes in China: Fashion, History, Nation, op. cit., pp. 108-09.

89. Dafeng archives, "List of the dealers piece goods sent us to be dyed" (original in English), 1924, in Maoli Yanghang you guan dianji deng baojia jishu ziliao (Documents and technical reports between Dafeng and the foreign company Maoli), 1925-1947, SMA, Q199-3-213, pp. 94-95.

90. According to a fieldwork investigation made by Arno S. Pearse, The Cotton Industry of Japan and China being the Report of the Journey to Japan and China, Manchester, Manchester International Cotton Federation, 1929, p. 181. In English, Dafeng was called China Dyeing Works, Ltd.

91. Yong'an Yuekan, No. 1, 1937, available in SMA, Q225-2-68. 